\title{
Evaluating the Stability of the Financial Ratios of Jordanian Industrial Companies
}

\author{
Ghaleb Abu Rumman \\ Assistant Professor (lecturer), Department of Accounting \\ School of Business, The University of Jordan, Amman Jordan \\ Imad Kutum (Corresponding author) \\ Visiting Assistant Professor, Department of Accounting \\ School of Business, The University of Jordan, Amman, Jordan \\ Tel: 1-905-330-6826Ｅmail: imad@kutum.com
}

DOI: 10.5296/ijafr.v5i1.7746 URL: http://dx.doi.org/10.5296/ ijafr.v5i1.7746

\begin{abstract}
The purpose of the study was to identify if the financial ratios of Jordanian industrial companies remained stable across sector and over time. The study used six financial ratios from fifty-six companies across six sectors with financial information from 2010 to 2014. A two way multivariate analysis of variance was performed to identify the stability of the ratios across the sectors and over the time. The results of the study showed that the financial ratios which showed some difference across sector were EBITTA (Earnings before Interest and Tax), CAT (Current Assets Turnover) and CFTA (Cash Flow to Total Assets). There were no differences observed between the financial ratios over time. The interaction of Time and Sector revealed no significant interaction effects. This suggests that as a whole, the financial ratios remained stable over time and sectors over the sectors and period chosen for the study.
\end{abstract}

Keywords: Financial Ratios, Stability of Financial Ratios, Jordan 


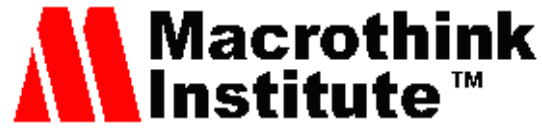

International Journal of Accounting and Financial Reporting ISSN 2162-3082 2015, Vol. 5, No. 1

\section{Introduction}

"One of the most fundamental facts about businesses is that the operating performance of the firm shapes its financial structure. It is also true that the financial situation of the firm can also determine its operating performance"(Zender, 2006). To know this for certain first of all is to adequately satisfy reporting standards and presentation procedures, and adhere to all regulations concerning financial reporting and auditing standards. This makes financial statements and reports very important diagnostic tools when it comes to financial planning and forecasting. The general belief that signs of financial crisis and difficulties can be observed years before occurrence is solidified when businesses can build financial models to evaluate risks and extract knowledge about their company's murky future (Lin, Liang, \& Chen, 2011).

Performance of companies financially can be ascertained through financial ratios. It enables companies to determine their financial strength or frailties. It also enables them to assess their risks and opportunities. Aside being able to make accurate predictions, ratios can provide the current position of the firm. Investors, banks and borrowers rely on ratios to assess the profitability and viability of dealing with a particular firm. Industrial analysis are done by aggregating financial statements of all the industry players for decision making by regulatory authorities. When it comes to managers deciding whether to shut down or continue operating a particular section of their business, ratios always provide the needed analysis for rational decision making.

'Financial Stability' as a phrase or a term has been an integral part of central banks and public regulatory bodies. According to Allen \& Wood (2006), "the Bank of England used the term in 1994, to denote those of its objectives which were not to do with price stability or with the efficient functioning of the financial system. 'The European Central Bank (2014), defines financial stability "as a condition in which the financial system-intermediaries, markets and market infrastructures - can withstand shocks without major disruption in financial intermediation and in the effective allocation of savings to productive investment. The three parts of the financial system: financial intermediaries, such as banks, insurance companies and other institutional investors that direct funds from those willing to invest/lend to those who want to borrow; financial markets, where lenders and borrowers meet, examples are money markets and stock exchanges; financial market infrastructures through which money and financial assets flow between buyers and sellers, examples are payment systems and security settlement systems. According to the ECB, the financial system can be said to be stable if it displays the following three key characteristics: the financial system should be able to efficiently and smoothly transfer resources from savers to investors; financial risks should be assessed and priced reasonably accurately and should also be relatively well managed; the financial system should be in such a condition that it can comfortably absorb financial and real economic surprises and shocks. If anyone or a combination of these characteristics is not being maintained, then it is likely that the financial system is moving in a direction of becoming less stable, and at some point might exhibit instability."

With this understanding, the need to safeguard financial stabilities, through the identification of the main risk sources, like the lack of prudence in the allocation of scarce resources. This must not be limited to only investors, but savers as well. This process is very vital for shrewd 


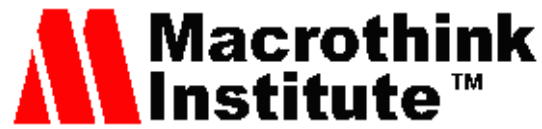

International Journal of Accounting and Financial Reporting ISSN 2162-3082 2015, Vol. 5, No. 1

financing. Also, "because the monitoring of financial stability must be forward looking: inefficiencies in the allocation of capital or shortcomings in the pricing and management of risk can, if they lay the foundations for vulnerabilities, compromise future financial system stability and therefore economic stability"(European Central Bank, 2014).According to IMF's Global Financial Stability Report, financial stability challenges are more persistent in developing economies and emerging markets. In recent times, bond sales have been more responsive to changes in adapting to monetary policies in developed economies because of foreign investments. The basic indicators that make emerging markets hopeful has also began to show some frailties, after a "protracted interval of credit expansion and rising corporate leverage." With all these uncertainties, policymakers would have to critically look at the risk management of transitioning to a more poised and maintainable financial sector (International Monetary Fund, 2014).

According to the World Bank (2015), Jordan has had success pursuing structural reforms in education, health and privatization and liberalization over the past 10 years. The Government of Jordan has been introducing social protection systems and reforming subsidies, creating the conditions for public-private partnerships in infrastructure and making tax reforms, including tax administration and management. The trade in goods balance widened in 2014 due to higher energy imports compensating the disruption of gas supply from Egypt. Despite larger financing of utility companies in 2014, the central government fiscal deficit improved thanks to continued fiscal consolidation efforts and a steadily expanding economy. While fiscal policy remains tight, the Central Bank of Jordan (CBJ) maintains its expansionary monetary policy. Real GDP growth is forecast at $3.5 \%$ in 2015 and $3.9 \%$ in 2016 due to stronger private consumption and investment, in part driven by lower oil prices and investment projects(World Bank, 2015).

Nevertheless, "Jordan faces daunting challenges due to the regional instability, high unemployment, a dependency on remittances from Gulf economies and continued pressure on natural resources. Diversifying Jordan's energy supply in the medium term will be indispensable in order to reduce the large twin deficits and macroeconomic vulnerabilities. Sound economic policies and growth-enhancing reforms will also be necessary to reduce the country's vulnerability to external shocks. Despite regional unrest and domestic disquiet, King Abdullah is expected to remain in power, supported by his loyal armed forces, and the government, led by Abdullah Ensour. The king will promote modest reform, but opposition activity will continue, including elements of the Muslim Brotherhood. The fiscal deficit will fall but remain large, keeping the government dependent on foreign support. Real GDP growth will be held back by regional instability in 2015-16, before strengthening in 2017-19"(EIU, 2015).

It has become imperative for Jordan to create conditions that will boost private and foreign investments, to hike competition and drive industrial growth, but most importantly, boost investor confidence. This will create jobs and ultimately reduce poverty. The proposed fiscal policies will prove to be challenging to implement, but it is highly recommended if the country is to create a conducive environment for industries to thrive and maintain stable financial ratios. 


\section{$\Lambda$ Macrothink}

International Journal of Accounting and Financial Reporting

ISSN 2162-3082

2015, Vol. 5, No. 1

\section{Literature Review}

The interest in financial ratios surged in the early 1920s, with researchers, businesses, universities, banks, and individuals taking keen interest in the subject. Earlier researchers like Justin (1924), called the ascertaining of data for ratio analysis and averages "Scientific ratio analysis". His use of the word scientific was highly debatable because no hypothesis testing was conducted to unearth any evidence to that effect.Horrigan (1968), was positive that the use of ratio analysis was going to exist in the foreseeable future, by making reference to its use in the past, to as far back as 300 B.C. in the evaluation of properties. The use of ratios currently are for the evaluation of companies and managerial decisions. It is also used for credit analysis by lending institutions and banks.

Financial ratios are widely known and accepted as tools used for financial projections and predictions. Researchers have used it to develop methodologies to conduct studies to predict the future of businesses being it a success or a failure (Altman, 1968; Beaver, 1966). Majority of studies on the subject in recent times concentrate on effectively predicting bankruptcy or the success or failure of a company based on current and past performances (Kumar \& Ravi, 2007).

Many of the recognized studies conducted on predicting the success or failures of companies are different from others because they employ distinct and unique set of tools and models, backed by sound interpretations (Alfaro, García, Gámez, \&Elizondo, 2008; Holsapple \& Wu, 2011; Lee, Han, \& Kwon, 1996; Martín-Oliver \& Salas-Fumás, 2012; Olson, Delen, \&Meng, 2012; Wilson \& Sharda, 1994). The only identified downside to their methods is the fact that they fail to unearth and elaborate on what can enhance the performance of a particular firm.

Gilman (1925), in his study criticized ratio analysis and had four concerns: "(1) ratios are bond with time and changed as time passed so cannot be interpreted (2) ratios are not natural measure for judging the performance companies manipulated them (3) ratios easily affect the mind of viewers and hide the actual position and (4) ratios swing widely that also affect the dependability. "Foulke (1945), decided to create and champion his own sets of financial ratios. It was successful nevertheless. They quickly gained prominence and their uses were quickly adopted for studies and risk evaluations.

\subsection{Empirical Literature}

Pinches, Mingo, and Caruthers (1973), conducted a study on the subject classification of financial ratios. They identified seven factors that they considered to be essential in any financial ratios classifications. They are receivable turnover, capital turnover, short-term liquidity, return on investment, inventory turnover, financial leverage and cash position. Pinches and Mingo (1973), conducted a study and found ratios to be best appreciated if classified into different groups. Their results classified ratios into four groups; financial leverage, short-term capital intensiveness, return on investment and long-term capital intensiveness. Chen and Shimerda (1981), conducted a thorough examination of five studies and realized most of the twelve factors under review were just classified under different names. They then found it rational to make their groupings seven, namely cash position, financial leverage, inventory turnover, short-term liquidity, return on investment, receivable turnover and capital turnover. Stevens (1973), also did a study on the classification of 


\section{Mll Macrothink}

International Journal of Accounting and Financial Reporting ISSN 2162-3082 2015, Vol. 5, No. 1

financial ratios. His also produced four main categories: activity, liquidity, leverage and profitability.

Zibanezhad, Foroghi, and Monadjemi (2011), effectively used classification and regression trees (C\&RT) to correctly predict bankruptcy using financial ratios and employing some vital variables. Rasmer and Foster (1931), in their study found that successful firms had higher ratios than unsuccessful ones, using eleven ratios. Further studies by other researchers and scholars found the study to be bias, but that was ultimately ignored because of the massive contribution it made to the subject. Saulnier \& Halcrow (1958), in their study found that firms which have a low current ratio and debt ratio are at risk of winding up than those with high ratios. Fitzpatrick (1932), conducted a study using thirteen different types of ratios to evaluate 120 companies which had failed. Findings revealed that three out of the thirteen ratios used for the evaluation correctly predicted the failure of firms, with others proving some prediction prowess.

Sun and Hui (2006), conducted a study on financial distress forecasting of some selected Chinese listed firms applying decision tree and genetic algorithms. Merwin (1942), conducted a study on a huge number of both successful and unsuccessful companies. The first analysis was comparing the ratios of unsuccessful firms with normal industrial ratios. Three of the ratios used: current ratio, net worth to debt and net working capital to total assets successfully predicted the failures of the firm before the firms could wind up. Hickman (1958), was able to used times interest earned ratio and net profit ratio to predict the default rate on corporate bond.

Wang, Jiang, and Wang (2009), employed the bagging-decision tree model to forecast stock returns by using fifty financial ratios on the financial data gathered. Gombola \& Ketz (1983), studied cash flow statements and realized that profitability ratios ascertained from income statements was different from that which the cash flow provided. They concluded that both ratios gave different but insightful findings on the subject. Beaver (1967), is widely credited for setting the foundation for further research on ratio analysis. The study added to the ability of ratios to predict failures. Findings showed that ratios can predict failures as early as five years before occurrence. Sorter \& Becker (1964), examined the relationship between psychological model and corporate personality of financial ratios and find out that long-established corporation maintain greater liquidity and solvency ratios.

\section{Methodology}

\subsection{Sample}

The research evaluates the stability of the financial ratios of the Jordanian industrial companies listed on Amman Stock Exchange across the different sectors and over a period of time. The data consists of fifty-six industrial companies across six industry sectors over five years i.e. from 2010 to 2014. The two independent variables are Sector and Time. The dependent variables are the six financial ratios calculated for the companies. The six industry sectors are:

\section{i. Pharmaceutical and Medical Industries \\ ii. Chemical Industries \\ iii. Food and Beverages}


iv. Mining and Extraction Industries

v. Engineering and Construction

vi. Textiles, Leather and Clothing

The number of companies in each industry sector is presented in Table 1 below.

Table 1: Industry Sectors of Companies

\begin{tabular}{ll}
\hline Sector & No of Companies \\
\hline Pharmaceutical and Medical Industries & 6 \\
Chemical Industries & 9 \\
Food and Beverages & 11 \\
Mining and Extraction Industries & 16 \\
Engineering and Construction & 8 \\
Textiles, Leather and clothing & 6 \\
Total & $\mathbf{5 6}$ \\
\hline
\end{tabular}

\subsection{Financial Ratios}

The ratios that were selected for the study are ratios which have been used and identified as effective in several past studies (Yap, Zulkifflee, \& Chong, 2013). The ratios are presented in Table 2 below.

\section{Table 2: Financial Ratios}

\begin{tabular}{|c|c|c|c|}
\hline Ratios & Codes & Calculated as & Measures \\
\hline $\begin{array}{l}\text { Earnings before } \\
\text { Interest and tax }\end{array}$ & EBITTA & $\begin{array}{l}\text { Net income before tax/ net } \\
\text { sales }\end{array}$ & Profitability \\
\hline $\begin{array}{l}\text { Current } \\
\text { Turnover }\end{array}$ & CAT & Net sales/Current assets & Operating Efficiency \\
\hline $\begin{array}{l}\text { Cash Flow to Total } \\
\text { Assets }\end{array}$ & CFTA & $\begin{array}{l}\text { Cash flow from Operations/ } \\
\text { Total Assets }\end{array}$ & Short-term Liquidity \\
\hline $\begin{array}{l}\text { Cash to Current } \\
\text { Liabilities }\end{array}$ & CCL & Cash/ Current Liabilities & Cash Position \\
\hline $\begin{array}{l}\text { Total Debts to Total } \\
\text { Assets }\end{array}$ & TDTA & Total Debts / Total Assets & Solvency \\
\hline $\begin{array}{l}\text { Total Debts to } \\
\text { Shareholders Funds }\end{array}$ & TDSF & $\begin{array}{l}\text { Total Debts / Shareholders } \\
\text { Fund }\end{array}$ & Solvency \\
\hline
\end{tabular}

Table 2 shows the financial ratios calculated, how they are calculated and the part of financial performance they are a measure of. EBITTA is a measure of profitability, CAT is a measure 


\section{Macrothink}

International Journal of Accounting and Financial Reporting

ISSN 2162-3082

2015, Vol. 5, No. 1

of operational efficiency, CFTA is a measure of short-term liquidity, CCL is a measure of cash position, TDTA is a measure of solvency as is TDSF.

\subsection{Statistical Analysis}

The researchers evaluate the financial ratios to identify their stability across sector and over time. Time and Sector are the independent variables and the six financial ratios are the dependent variables. The researchers therefore chose the two way multivariate analysis of variance as the statistical test to use. The test was performed with SPSS. The results will show if there are significant differences in the means of the six sectors and whether there are significant differences in the means of the ratios over the five year period.

\section{Results and Discussions}

The first test to be used is Levene's Test of Equality of Error Variances. The significance value is set at 0.05 . If the significance value is lower than 0.05 , then it means there was significant differences in the variances over sector and time. A significance value greater than 0.05 will indicate homogeneity of variances. The results of Levene's test are presented in Table 3 below.

Table 3: Levene's Test of Equality of Error Variances

\begin{tabular}{llllll}
\hline Codes & Ratios & F & df1 & df2 & Sig. \\
\hline EBITTA & Earnings before Interest and tax & 1.053 & 29 & 234 & .398 \\
CAT & Current Assets Turnover & & & & \\
CFTA & Cash Flow to Total Assets & 4.714 & 29 & 234 & .000 \\
& & & & & \\
CCL & Cash to Current Liabilities & 1.560 & 29 & 234 & .039 \\
& & 1.974 & 29 & 234 & .003 \\
TDTA & Total Debts to Total Assets & & & & \\
& & 1.909 & 29 & 234 & .005 \\
TDSF & Total Debts to Shareholders Funds & 1.909 & 29 & 234 & .005 \\
\hline
\end{tabular}

Table 3 shows the results of Levene's Test of Equality of Error Variances. The only variable which shows that there is homogeneity of variance is EBITTA with a p-value of 0.398 . All the other variables have p-values $<0.05$ and therefore the variances are unequal. To find out what samples are different, the Tukey post hoc test is used. 
Table 4: Multiple Comparisons across Sectors 2015, Vol. 5, No. 1

\begin{tabular}{|c|c|c|c|c|c|c|c|}
\hline & & EBITTA & CAT & CFTA & CCL & TDTA & TDSF \\
\hline Sector & Sector & Sig. & Sig. & Sig. & Sig. & Sig. & Sig. \\
\hline \multirow[t]{5}{*}{ Chemical Industries } & $\begin{array}{l}\text { Engineering and } \\
\text { Construction }\end{array}$ & .999 & 1.000 & 1.000 & 1.000 & 1.000 & 1.000 \\
\hline & Food and Beverages & .998 & .000 & .444 & .772 & .863 & .863 \\
\hline & $\begin{array}{l}\text { Mining and Extraction } \\
\text { Industries }\end{array}$ & .475 & 1.000 & .958 & .164 & .732 & .732 \\
\hline & $\begin{array}{l}\text { Pharmaceutical and } \\
\text { Medical Industries }\end{array}$ & .967 & .997 & .998 & 1.000 & .620 & .620 \\
\hline & $\begin{array}{l}\text { Textiles, Leathers and } \\
\text { Clothing }\end{array}$ & .670 & .995 & .313 & .994 & .965 & .965 \\
\hline \multirow{5}{*}{$\begin{array}{l}\text { Engineering } \\
\text { Construction }\end{array}$} & Chemical Industries & .999 & 1.000 & 1.000 & 1.000 & 1.000 & 1.000 \\
\hline & Food and Beverages & .964 & .000 & .452 & .654 & .951 & .951 \\
\hline & $\begin{array}{l}\text { Mining and Extraction } \\
\text { Industries }\end{array}$ & .785 & 1.000 & .973 & .113 & .882 & .882 \\
\hline & $\begin{array}{l}\text { Pharmaceutical and } \\
\text { Medical Industries }\end{array}$ & .995 & .999 & .997 & 1.000 & .730 & .730 \\
\hline & $\begin{array}{l}\text { Textiles, Leathers and } \\
\text { Clothing }\end{array}$ & .473 & .997 & .364 & .977 & .922 & .922 \\
\hline \multirow[t]{5}{*}{ Food and Beverages } & Chemical Industries & .998 & .000 & .444 & .772 & .863 & .863 \\
\hline & $\begin{array}{l}\text { Engineering and } \\
\text { Construction }\end{array}$ & .964 & .000 & .452 & .654 & .951 & .951 \\
\hline & $\begin{array}{l}\text { Mining and Extraction } \\
\text { Industries }\end{array}$ & .159 & .000 & .034 & .909 & 1.000 & 1.000 \\
\hline & $\begin{array}{l}\text { Pharmaceutical and } \\
\text { Medical Industries }\end{array}$ & .875 & .003 & .972 & .913 & .960 & .960 \\
\hline & $\begin{array}{l}\text { Textiles, Leathers and } \\
\text { Clothing }\end{array}$ & .855 & .000 & .003 & .991 & .432 & .432 \\
\hline \multirow{4}{*}{$\begin{array}{l}\text { Mining and Extraction } \\
\text { Industries }\end{array}$} & Chemical Industries & .475 & 1.000 & .958 & .164 & .732 & .732 \\
\hline & $\begin{array}{l}\text { Engineering } \\
\text { Construction }\end{array}$ & .785 & 1.000 & .973 & .113 & .882 & .882 \\
\hline & Food and Beverages & .159 & .000 & .034 & .909 & 1.000 & 1.000 \\
\hline & $\begin{array}{l}\text { Pharmaceutical and } \\
\text { Medical Industries }\end{array}$ & 1.000 & 1.000 & .911 & .554 & .974 & .974 \\
\hline
\end{tabular}




\begin{tabular}{|c|c|c|c|c|c|c|c|}
\hline & $\begin{array}{l}\text { Textiles, Leathers and } \\
\text { Clothing }\end{array}$ & .019 & .999 & .647 & .678 & .287 & .287 \\
\hline \multirow{5}{*}{$\begin{array}{l}\text { Pharmaceutical } \\
\text { Medical Industries }\end{array}$} & Chemical Industries & .967 & .997 & .998 & 1.000 & .620 & .620 \\
\hline & $\begin{array}{l}\text { Engineering and } \\
\text { Construction }\end{array}$ & .995 & .999 & .997 & 1.000 & .730 & .730 \\
\hline & Food and Beverages & .875 & .003 & .972 & .913 & .960 & .960 \\
\hline & $\begin{array}{l}\text { Mining and Extraction } \\
\text { Industries }\end{array}$ & 1.000 & 1.000 & .911 & .554 & .974 & .974 \\
\hline & $\begin{array}{l}\text { Textiles, Leathers and } \\
\text { Clothing }\end{array}$ & .440 & 1.000 & .390 & .996 & .304 & .304 \\
\hline \multirow{5}{*}{$\begin{array}{l}\text { Textiles, Leathers and } \\
\text { Clothing }\end{array}$} & Chemical Industries & 670 & .995 & .313 & .994 & .965 & .965 \\
\hline & $\begin{array}{l}\text { Engineering } \\
\text { Construction }\end{array}$ & .473 & .997 & .364 & .977 & .922 & .922 \\
\hline & Food and Beverages & .855 & .000 & .003 & .991 & .432 & .432 \\
\hline & $\begin{array}{l}\text { Mining and Extraction } \\
\text { Industries }\end{array}$ & .019 & .999 & .647 & .678 & .287 & .287 \\
\hline & $\begin{array}{l}\text { Pharmaceutical and } \\
\text { Medical Industries }\end{array}$ & .440 & 1.000 & .390 & .996 & .304 & .304 \\
\hline
\end{tabular}

The results of the Tukey test in Table 4 above show whether the means of the means of the financial ratios across the six sectors are homogenous. A p-value $<0.05$ indicates a significant difference while a p-value $>0.05$ indicates that there is no significant difference between the means of the sectors. The table shows that the only ratios in which significant differences were identified were EBITTA, CAT and CFTA. All the other financial ratios did not show any significant difference across the sectors. For EBITTA, significant differences were observed between Mining and Extraction and Textiles, Leathers and Clothing. For CAT, significant differences were observed between Food and Beverages and all the other sectors. Significant differences were observed between the Food and Beverages and Textiles, Leathers and Clothing; Mining and Extraction and Food and Beverages; and Textiles, Leathers, Clothing and Food and Beverages sectors of CFTA. 
Table 5: Multiple Comparisons over Time

\begin{tabular}{|c|c|c|c|c|c|c|c|}
\hline & & EBITTA & CAT & CFTA & CCL & TDTA & TDSF \\
\hline Years & Years & Sig. & Sig. & Sig. & Sig. & Sig. & Sig. \\
\hline \multirow[t]{4}{*}{2010} & 2011 & 1.000 & .998 & .239 & .917 & .926 & .926 \\
\hline & 2012 & .982 & .999 & .175 & 1.000 & .662 & .663 \\
\hline & 2013 & .952 & .991 & .077 & .999 & .975 & .975 \\
\hline & 2014 & .849 & 1.000 & .056 & .999 & .847 & .847 \\
\hline \multirow[t]{4}{*}{2011} & 2010 & 1.000 & .998 & .239 & .917 & .926 & .926 \\
\hline & 2012 & .977 & .980 & 1.000 & .923 & .984 & .984 \\
\hline & 2013 & .943 & 1.000 & .985 & .809 & 1.000 & 1.000 \\
\hline & 2014 & .830 & .986 & .968 & .810 & 1.000 & 1.000 \\
\hline \multirow[t]{4}{*}{2012} & 2010 & .982 & .999 & .175 & 1.000 & .662 & .663 \\
\hline & 2011 & .977 & .980 & 1.000 & .923 & .984 & .984 \\
\hline & 2013 & 1.000 & .956 & .996 & .999 & .944 & .944 \\
\hline & 2014 & .990 & 1.000 & .989 & .999 & .997 & .997 \\
\hline \multirow[t]{4}{*}{2013} & 2010 & .952 & .991 & .077 & .999 & .975 & .975 \\
\hline & 2011 & .943 & 1.000 & .985 & .809 & 1.000 & 1.000 \\
\hline & 2012 & 1.000 & .956 & .996 & .999 & .944 & .944 \\
\hline & 2014 & .998 & .967 & 1.000 & 1.000 & .994 & .994 \\
\hline \multirow[t]{4}{*}{2014} & 2010 & .849 & 1.000 & .056 & .999 & .847 & .847 \\
\hline & 2011 & .830 & .986 & .968 & .810 & 1.000 & 1.000 \\
\hline & 2012 & .990 & 1.000 & .989 & .999 & .997 & .997 \\
\hline & 2013 & .998 & .967 & 1.000 & 1.000 & .994 & .994 \\
\hline
\end{tabular}

Table 5 above presents the Tukey post hoc tests comparing the means of the six financial ratios over time. A p-value $>0.05$ indicates that there was no significant difference between the means of the financial ratios over the five year period. A p-value $<0.05$ however indicates that there was significant differences between the means of the financial ratios. The test showed that there was no significant differences between the means of any of the financial ratios over the five year period of 2010 to 2014 . 
Table 6: Test of Between Subject Effects

\begin{tabular}{|c|c|c|c|c|c|}
\hline Source & $\begin{array}{l}\text { Dependent } \\
\text { Variable }\end{array}$ & $\begin{array}{l}\text { Type III Sum of } \\
\text { Squares }\end{array}$ & Mean Square & $\mathbf{F}$ & Sig. \\
\hline \multirow{6}{*}{$\begin{array}{l}\text { Corrected } \\
\text { Model }\end{array}$} & EBITTA & $16.836^{\mathrm{a}}$ & .581 & .675 & .897 \\
\hline & CAT & $912.981^{\mathrm{b}}$ & 31.482 & 1.740 & .014 \\
\hline & CFTA & $.418^{\mathrm{c}}$ & .014 & 1.669 & .021 \\
\hline & CCL & $160.888^{\mathrm{d}}$ & 5.548 & .565 & .966 \\
\hline & TDTA & $106475770.063^{\mathrm{e}}$ & 3671578.278 & .548 & .973 \\
\hline & TDSF & $106463225.027^{\mathrm{f}}$ & 3671145.691 & .548 & .973 \\
\hline \multirow[t]{6}{*}{ Intercept } & EBITTA & .581 & .581 & .675 & .412 \\
\hline & CAT & 612.945 & 612.945 & 33.875 & .000 \\
\hline & CFTA & .372 & .372 & 43.081 & .000 \\
\hline & CCL & 78.966 & 78.966 & 8.046 & .005 \\
\hline & TDTA & 193074478.868 & 193074478.868 & 28.797 & .000 \\
\hline & TDSF & 193081230.087 & 193081230.087 & 28.801 & .000 \\
\hline \multirow[t]{6}{*}{ Year } & EBITTA & 1.372 & .343 & .399 & .809 \\
\hline & CAT & 7.581 & 1.895 & .105 & .981 \\
\hline & CFTA & .032 & .008 & .939 & .442 \\
\hline & $\mathrm{CCL}$ & 9.994 & 2.499 & .255 & .907 \\
\hline & TDTA & 14191034.625 & 3547758.656 & .529 & .714 \\
\hline & TDSF & 14188510.416 & 3547127.604 & .529 & .714 \\
\hline \multirow[t]{5}{*}{ Sector } & EBITTA & 11.200 & 2.240 & 2.606 & .026 \\
\hline & CAT & 847.818 & 169.564 & 9.371 & .000 \\
\hline & CFTA & .144 & .029 & 3.340 & .006 \\
\hline & $\mathrm{CCL}$ & 100.828 & 20.166 & 2.055 & .072 \\
\hline & TDTA & 54494739.217 & 10898947.843 & 1.626 & .154 \\
\hline
\end{tabular}




\begin{tabular}{|c|c|c|c|c|c|}
\hline & TDSF & 54490792.215 & 10898158.443 & 1.626 & .154 \\
\hline \multirow{6}{*}{$\begin{array}{l}\text { Year } \\
\text { Sector }\end{array}$} & EBITTA & 4.274 & .214 & .249 & 1.000 \\
\hline & CAT & 50.002 & 2.500 & .138 & 1.000 \\
\hline & CFTA & .189 & .009 & 1.095 & .356 \\
\hline & CCL & 43.945 & 2.197 & .224 & 1.000 \\
\hline & TDTA & 40362061.938 & 2018103.097 & .301 & .999 \\
\hline & TDSF & 40359425.221 & 2017971.261 & .301 & .999 \\
\hline \multirow[t]{6}{*}{ Error } & EBITTA & 201.165 & .860 & & \\
\hline & CAT & 4234.065 & 18.094 & & \\
\hline & CFTA & 2.020 & .009 & & \\
\hline & $\mathrm{CCL}$ & 2296.627 & 9.815 & & \\
\hline & TDTA & 1568868477.061 & 6704566.141 & & \\
\hline & TDSF & 1568745642.529 & 6704041.207 & & \\
\hline \multirow[t]{6}{*}{ Total } & EBITTA & 219.666 & & & \\
\hline & CAT & 6218.214 & & & \\
\hline & CFTA & 2.951 & & & \\
\hline & $\mathrm{CCL}$ & 2651.138 & & & \\
\hline & TDTA & 1926411703.338 & & & \\
\hline & TDSF & 1926282334.162 & & & \\
\hline \multirow{6}{*}{$\begin{array}{l}\text { Corrected } \\
\text { Total }\end{array}$} & EBITTA & 218.001 & & & \\
\hline & CAT & 5147.047 & & & \\
\hline & CFTA & 2.438 & & & \\
\hline & CCL & 2457.515 & & & \\
\hline & TDTA & 1675344247.123 & & & \\
\hline & TDSF & 1675208867.555 & & & \\
\hline
\end{tabular}




\section{Macrothink}

International Journal of Accounting and Financial Reporting

ISSN 2162-3082

2015, Vol. 5, No. 1

Table 6 above presents the analysis of the effects of Sector, effects of Time and the effects of the interaction of Sector and Time. The effect of the individual independent variables on the dependent variables is known as the main effect. This effect ignores the effect of the other independent variables. The interaction effect of the two independent variables on the dependent variables is observed in Sector*Time. A p-value of less than 0.05 indicates that there is significant difference and a p-value greater than 0.05 indicates that there is no significant difference.

The results show that there was no significant main effects between Time and the financial ratios. Significant main effects were identified between Sector and some of the dependent variables. The significant main effects across sector was identified for EBITTA (p-value = 0.026), CAT (p-value $=0.000)$ and CFTA ( $p$-value $=0.006)$. No significant main effects were identified for CCL, TDTA and TDSF. There was no interaction effects between Sector and Time.

\section{Conclusions}

The results of the study show that the financial ratios which were different across industry were EBITTA (Earnings before Interest and Tax), CAT (Current Assets Turnover) and CFTA (Cash Flow to Total Assets). For Earnings before Interest and Tax, differences were observed between the Mining and Extraction and Textiles, Leathers and Clothing. For Current Assets Turnover, differences were observed in the financial ratios between Food and Beverages and all the other five sectors. Differences were observed for Cash Flow to Total Assets between the Food and Beverages and the Textiles, Leather and Clothing industries and the Mining and Extraction and Food and Beverages sectors.

There were no differences observed between the financial ratios over time. The financial ratios were stable over the time period of 2010 to 2014. There were no significant changes observed in any of the financial ratios from year to year.

The interaction of Time and Sector revealed no significant interaction effects. This suggests that as a whole, the financial ratios remained stable over time and sectors over the sectors and period chosen for the study.

A study of Malaysian companies (Yap, Zulkifflee, \& Chong, 2013) revealed similar results. The results of that study were that EBITTA, CCL, TDTA and TDSF varied across some industries but did not vary over time and there were no significant interaction effects between Time and Sector. The conclusion of this research further reaffirms their conclusion that financial ratios generally remain stable across different industries and over time.

The research is limited by the fact that it only covers 56 companies from Jordan over 5 years and across 6 sectors. Further studies in other markets, different sectors and over different sectors could be undertaken to see if the results would be similar. 


\section{References}

Alfaro, E., García, N., Gámez, M., \& Elizondo, D. (2008). Bankruptcy forecasting: An empirical comparison of AdaBoost and neural networks. Decision Support System, 110-122.

Allen, W. A., \& Wood, G. (2006). Defining and achieving financial stability. Journal of financial stability, 152-172.

Altman, E. I. (1968). Financial ratios, discriminant analysis and the predication of corporate bankruptcy. The Journal of Finance, 589-609.

Beaver, W. (1967). Financial Ratio as Predictors of Failure, Empirical Research in Accounting: Selected Studies 1966 . Journal of Accounting Research, 71-111.

Beaver, W. H. (1966). Financial ratios as predictors of failure. Empirical Research in Accounting: Selected Studies. Supplement to Journal of Accounting Research, 71-111.

Chen, K. H., \& Shimerda, T. A. (1981). An empirical analysis of useful financial ratios. Financial Management, 51-60.

Delen, D., Kuzey, C., \& Uyar, A. (2013). Measuring firm performance using financial ratios: A decision tree approach. Expert Systems with Applications, 3970-3983.

EIU. (2015). Jordan in Brief. Cabot Square, London: The Economist Intelligence Unit. Retrieved from http://country.eiu.com/jordan

European Central Bank. (2014). Financial Stability Review. Frankfurt am Main: ECB. Retrieved from https://www.ecb.europa.eu/pub/fsr/html/index.en.html

Fitzpatrick, P. (1932). A Comparison of the Ratios of Successful Industrial Enterprises with those of Failed Companies. The Accountants Publishing Company.

Foulke, R. (1945). Practical Financial Statement Analysis. New York: McGraw-Hill Book Company Inc.

Gilman, S. (1925). Analyzing Financial Statements. New York: The Ronald Press Company.

Gombola, M. J., \& Ketz, J. E. (1983). A note on cashflow and classification patterns of financial raatios. Accounting Review, 105-114.

Hickman, W. B. (1958). Corporate Bond Quality and Investor Experience. New Jersey: Princiton University Press.

Holsapple, C. W., \& Wu, J. (2011). An elusive antecedent of superior firm performance: The knowledge management factor. Decision Support Systems, 271-283.

Horrigan, J. (1968). A Short History of Financial Ratio Analysis. The Accounting Review, 284-294.

International Monetary Fund. (2014). Global Financial Stability Report: Transition Challenges to Stability. Washington, DC : World Economic and Financial Surveys.

Justin, W. (1924). Operating Control Through Scientific Analysis. The Journal of Accountancy, 183-95.

Kumar, P. R., \& Ravi, V. (2007). Bankruptcy prediction in banks and firms via statistical and intelligent techniques - A review. European Journal of Operations Research, 1-28.

Lee, K. C., Han, I., \& Kwon, Y. (1996). Hybrid neural network models for bankruptcy 
predictions. Decision Support Systems, 63-72.

Lin, F., Liang, D., \& Chen, E. (2011). Financial ratio selection for business crisis prediction. Expert Systems with Applications, 15094-15102.

Martín-Oliver, A., \& Salas-Fumás, V. (2012). IT assets, organization capital and market power: Contributions to business value. Decision Support Systems, 612-623.

Merwin, C. (1942). Financing Small Corporations in Five Manufacturing Industries,. National Bureau of Economic Research., 1926-1936.

Olson, D. L., Delen, D., \& Meng, Y. (2012). Comparative analysis of data mining methods for bankruptcy prediction. Decision Support Systems, 464-473.

Oosterloo, S., Haanb, J. d., \& Jong-A-Pin, R. (2007). Financial stability reviews: A first empirical analysis. Journal of Financial Stability, 337-355.

Pinches, G. E., Mingo, K. A., \& Caruthers, J. K. (1973). The stability of financial patterns in industrial organizations. The Journal of Finance, 389-396.

Ramser, J., \& Foster, L. (1931). A Demonstration of Ratio Analysis. Bulletin No. 40, Urbana, Ill. Bureau of Business Research.

Saulnier, R. J., \& Halcrow, H. G. (1958). Federal Lending and Loan Insurance. New Jersey: Princeton University Press.

Sorter, G., \& Becker, S. (1964). Accounting and financial decisions and corporate personality- some preliminary findings. Journal of Accounting Research, 183-196.

Stevens, D. L. (1973). Financial Characteristics of Merged Firms: A Multivariate Analysis. Journal of Financial and Quantitative Analysis, 149-158.

Sun, J., \& Hui, X.-F. (2006). An application of decision tree and genetic algorithms for financial ratios' dynamic selection and financial distress prediction. the fifth international conference on machine learning and cybernetics, (pp. 13-16). Dalian.

Wang, H., Jiang, Y., \& Wang, H. (2009). Stock return prediction based on baggingdecision tree. 2009 IEEE international conference on grey systems and intelligent services, (pp. 10-12). Nanjing.

Wilson, R. L., \& Sharda, R. (1994). Bankruptcy prediction using neural networks. Decision Support Systems, 545-557.

World Bank. (2015). Jordan Overview. Washington: Jordan Economic Monitor. Retrieved from http://www.worldbank.org/en/country/jordan/overview

Yap, B. C.-F., Zulkifflee, M., \& Chong, K.-R. (2013). A Longitudinal and Cross-Industry Study on the Stability of Financial Ratios of Malaysian Companies. Accounting and Finance Research, 45-52.

Zender, J. F. (2006). Evaluating Financial Performance. Higgins .

Zibanezhad, E., Foroghi, D., \& Monadjemi, A. (2011). Applying decision tree to predict bankruptcy. Computer Science and Automation Engineering (CSAE). IEEE International Conference, (pp. 165-169). 